\title{
REPRODUCIBILITY AND EQUIVALENCE OF COBBMETER APPLICATION IN THE SAGITTAL EVALUATION OF THE SPINE
}

\author{
REPRODUTIBILIDADE E EQUIVALÊNCIA DO APLICATIVO COBBMETER \\ NA AVALIAÇÃO SAGITAL DA COLUNA \\ REPRODUCIBILIDAD Y EQUIVALENCIA DE LA APLICACIÓN COBBMETER \\ EN LA EVALUACIÓN SAGITAL DE LA COLUMNA VERTEBRAL
}

Luis Marchi' ${ }^{1}$, Fernanda Fortti ${ }^{1}$, Rodrigo Amaral ${ }^{1}$, Leonardo Oliveira ${ }^{1}$, Joes Nogueira-Neto ${ }^{1}$, Rubens Jensen ${ }^{1}$, Luiz Pimenta ${ }^{1}{ }^{2}$

1. Instituto de Patologia da Coluna, São Paulo, SP, Brazil.

2. University of California San Diego, San Diego, CA, USA.

\begin{abstract}
Objective: This study aims to evaluate the reliability and equivalency of using the Cobbmeter application for iPhone compared to the manual measurement method in the analysis of the sagittal spinal alignment. Methods: Cross-sectional, prospective, single-center study that had 20 panoramic radiographs of the spine in lateral view, in a neutral standing position, analyzed blindly and randomly by three independent examiners in three different times. The parameters were pelvic incidence (PI), pelvic tilt (PT) and lumbar lordosis (LL). The statistical analysis was performed to measure the intraclass correlation coefficient (ICC) between the two measurement methods, in addition to measuring the intra and inter-evaluators reliability. Results: For reproducibility analysis, the intra-evaluators ICC using the application resulted in a Kappa $(\mathrm{K})$ of 0.975 for the evaluation of pelvic incidence (PI) evaluation. For pelvic tilt (PT), the K value obtained was 0.981 and the $\mathrm{K}$ measured for lumbar lordosis (LL) analysis was 0.987 . The inter-evaluators evaluation of reproducibility using the application resulted in a $\mathrm{K}$ value of 0.917 for $\mathrm{PI}, 0.930$ for $\mathrm{PT}$ and 0.951 for $\mathrm{LL}$. For the assessment of equivalency of methods, comparing the application to the standard method, with a goniometer and dermographic pencil, the K value found for PI was 0.873 , for PV was 0.939 and for $L L$ was 0.914 . All values were significant $(p<0.001)$ against the null hypothesis. Conclusion: This smartphone application is a valid and reliable instrument for measuring the angle involved in the sagittal balance of the spine. Furthermore, the results show that its applicability is not inferior to the manual method with goniometer and dermographic pencil.
\end{abstract}

Keywords: Spine; Diagnostic imaging; Postural balance; Lordosis; Kyphosis; Pelvis.

\section{RESUMO}

Objetivo: Este trabalho visa avaliar a confiabilidade e a equivalência da utilização do aplicativo Cobbmeter para iPhone em comparação com o método de medição manual na análise do alinhamento sagital da coluna vertebral. Métodos: Estudo transversal, prospectivo, de centro único, em que foram analisadas, de forma cega e aleatória, 20 radiografias panorâmicas de coluna vertebral em incidência lateral, em posição ortostática neutra, por três examinadores independentes, em três momentos diferentes. Os parâmetros encontrados foram: incidência pélvica (IP), versão pélvica (VP) e lordose lombar (LL). A análise estatística foi aplicada para medir o coeficiente de correlação intraclasse (CCl) entre os dois métodos de medição, além de medir a confiabilidade intra e interavaliador. Resultados: Para análise de reprodutibilidade, o CCl intra-avaliador, utilizando-se o aplicativo, resultou em um Kappa (K) de 0,975 para a avaliação de incidência pélvica (IP). Para versão pélvica (VP), o K encontrado foi 0,981 e o K medido para a análise de lordose lombar (LL) foi 0,987. A avaliação da reprodutibilidade interavaliador, utilizando-se o aplicativo, resultou em um K de 0,917 para a avaliação da IP, de 0,930 para a VP e de 0,951 para a LL. Para a avaliação de equivalência dos métodos, comparando-se o aplicativo ao método padrão, com goniômetro e lápis dermatográfico, o K encontrado na medição de IP foi 0,873, 0,939 para VP e 0,914 para LL. Todos os valores foram significativos $(p<0,001)$ contra a hipótese nula. Conclusões: Esse aplicativo para smartphone é um instrumento válido e confiável para a medição dos ângulos envolvidos no equilíbrio sagital da coluna vertebral. Além disso, os resultados mostram que sua aplicabilidade é não inferior ao método manual com goniômetro e lápis dermatográfico.

Descritores: Coluna vertebral; Diagnóstico por imagem; Equilíbrio postural; Lordose; Cifose; Pelve.

\section{RESUMEN}

Objetivo: Este trabajo tiene como objetivo evaluar la fiabilidad y la equivalencia de utilizar la aplicación Cobbmeter para iPhone en comparación con el método de medición manual en el análisis de la alineación sagital de la columna. Métodos: Estudio transversal, prospectivo, en un solo centro, donde fueron analizadas a ciegas y aleatoriamente 20 radiografías panorámicas de la columna vertebral en vista lateral, en posición ortostática neutra, por tres examinadores independientes en tres ocasiones diferentes. Los parámetros obtenidos fueran: incidencia pélvica (IP), versión pélvica (VP) y lordosis lumbar (LL). Se aplicó análisis estadístico para medir el coeficiente de correlación intraclase (CCI) entre los dos métodos de medición, además de medir la fiabilidad intra e inter-observador. Resultados: Para el análisis de la reproducibilidad, el CCl intra-observador, con el uso de la aplicación, resultó en un Kappa (K) de 0,975 para la evaluación de la incidencia pélvica (IP). Para la versión pélvica (VP), el K encontrado fue de 0,981 y el K medido para el análisis de la lordosis lumbar (LL) fue 0,987. La evaluación de la reproducibilidad intra-evaluador, utilizando la aplicación, resultó en K de 0,917 para 
la evaluación de IP, de 0,930 para VP y de 0,951 para la LL. Para la evaluación de la equivalencia de los métodos, comparándose la aplicación con el método estándar con goniómetro y lápiz dermográfico, el K encontrado en la medición de IP fue 0,873, de la VP fue 0,939 y de la LL fue 0,914. Todos los valores fueran significativos $(p<0,001)$ contra la hipótesis nula. Conclusión: Esta aplicación para smartphones es un instrumento válido y fiable para medir los ángulos que intervienen en el equilibrio sagital de la columna vertebral. Además, los resultados muestran que su aplicabilidad es no inferior que el método manual con goniómetro y lápiz dermográfico.

Descriptores: Columna vertebral; Diagnóstico por imagen; Balance postural; Lordosis; Cifosis; Pelvis.

\section{INTRODUCTION}

Sagittal alignment of the spine is a concept based on the understanding and treatment of various spine pathologies. ${ }^{1-8}$ The correct alignment of the bony structures and their articulations is fundamental to the proper functioning of the musculoskeletal system. ${ }^{9}$ Furthermore, their complex interactions with the nervous system and subsequent muscle recruitment are essential to ergonomic balance and the maintenance of upright posture with minimal energetic expenditure, thus allowing the deliberate movement of the human body. ${ }^{10-12}$

Currently, the parameters used in the radiological evaluation of overall sagittal balance include the morphology and position of the pelvis, which act as regulators of sagittal alignment, ${ }^{9}$ among other spinal parameters. The spino-pelvic parameters are key components in the evaluation and treatment of sagittal deformities ${ }^{9}$ and also of degenerative pathologies of the spine, as correct sagittal alignment directly impacts the quality of life of these patients. ${ }^{13,14}$ The current standard for acquiring the measurements uses manual measuring of these parameters with a goniometer, a process that requires a dermatograph pencil for drawing lines on the radiographic film, as well as the goniometer itself, which the clinician many times does not have on hand. ${ }^{15}$

Recently, with the inclusion of technological tools in medical practice, these technologies can be used to assist physicians in clinical practice. The growing interaction between technology and clinical practice has enabled both time savings and the maintenance of communication between health professionals and their patients even outside the workplace. ${ }^{16}$ And the measurement of spino-pelvic parameters can be accomplished through digital means, using programs and applications available on different platforms, such as computers and smartphones, for example.

The current generation of smartphones has incorporated an accelerometer based on microelectromechanical systems (MEMS) that is sensitive to the acceleration and the inclination of the apparatus with precision of $1 / 10$ of a degree, providing much greater accuracy in measuring spino-pelvic parameters as compared to measurements obtained from drawing lines on radiographic film. ${ }^{17,18}$ However, today the manual measurement of spino-pelvic parameters remains the standard method for acquiring these parameters.

Thus, this study aims to verify the equivalence and intra- and inter-evaluator reproducibility of an application called CobbMeter ${ }^{15}$ (CobbMeter, Altavi, Luxembourg) in the clinical practice of spine surgeons, comparing it to the current standard of measurement using a goniometer and dermatograph pencil, in order to confirm whether it is possible for a greater number of medical service providers to trust using a tool capable of providing reliable measurements, with a better cost-benefit ratio and greater convenience in clinical practice.

\section{METHOD}

For the development of this study, 20 panoramic lateral view $x$-ray films of the spine in neutral standing position, in which it was possible to identify the vertebral plateaus and femur heads (with at least 50\% overlap), were analyzed. Patients with prior hip arthroplasty or who did not meet the inclusion criteria were excluded. All the patients included in the study agreed voluntarily to participate in the study and signed the Informed Consent Form (ICF), and the study was authorized by the Institutional Review Board (CAAE 45924615.8.0000.0086).

After collecting the 20 imaging exams, the author de-identified them and assigned a reference code to each. In the first phase, all the exams were presented to three different evaluators: two experienced physicians specializing in the spine and one researcher with extensive experience in the area of the spine, following the model proposed by Ritter et al. ${ }^{19}$ Measurements of the lumbar lordosis (LL), pelvic tilt (PT), and pelvic incidence $(\mathrm{PI})$ were taken as described by Berthonnaud et al. ${ }^{20}$ and using the Portuguese nomenclature standardized by Pratali et al. ${ }^{21}$ The positioning of the smartphone was standardized for all the measurements and is illustrated in Figure 1. The LL was obtained by measuring the angle between the upper plateau of the L1 vertebra and the upper plateau of the S1 vertebra. The PT was acquired by measuring the angle obtained by the line formed between the midpoint of the segment that joins the centers of the femur heads and the midpoint of the upper plateau of vertebra S1 in relation to the vertical line that originates in the center, at the midpoint of the segment that joins the centers of the femur heads. The PI corresponds to the angle obtained from the line formed between the midpoint of the segment that joins the centers of the femur heads and the midpoint of the upper vertebral plate of the S1 vertebra in relation to the line perpendicular to the sacral plateau.

First, the data was collected using the CobbMeter application (CobbMeter CE, Regis Rigal, Version 2.5.2), running on a single Apple iPhone device (Apple Inc., Cupertino, USA) and then, after shuffling the order of the exams, the data was collected using a goniometer and a dermatograph pencil. In the second phase, a week following the first exposure, the same exams were presented at random to the evaluators who measured them again, using first the CobbMeter application and second a goniometer and dermatograph pencil, in the same form as in the first evaluation. Finally, in the third phase, 14 days following the first exposure, the same methodology was used to collect the measurements.

The data collected were plotted in a spreadsheet and complied for subsequent statistical analysis by the author. The compiled data were analyzed using the SPSS 20.0 program (IBM Corporation, Armonk, NY, USA). The intra-class correlation coefficients (ICC) were computed using the two-way effect model to test intra- and inter-evaluator consistency. The results of the ICC were interpreted according to the following scale: 0 to 0.24 , absent or poor consistency; 0.25 to 0.49 , low consistency; 0.50 to 0.69 , moderate consistency; 0.70 to 0.89 , good consistency; and 0.90 to 1.0 , excellent consistency. ${ }^{22}$

\section{RESULTS}

For the reproducibility analysis, the intra-evaluator ICC, using the application, yielded a Kappa (K) for the evaluation of pelvic incidence (PI) of $0.975(p<0.001)$. For pelvic tilt (PT), the $K$ found was $0.981(p<0.001)$ and for the analysis of lumbar lordosis (LL) the K $0.987(p<0.001)$

Also in the reproducibility evaluation, the inter-evaluator assessment, using the application, yielded a K of $0.917(p<0.001)$ for the PI evaluation. For PT, the $K$ found was $0.930(p<0.001)$ and the $\mathrm{K}$ measured in the analysis of LL was $0.951(p<0.001)$.

For the assessment of equivalence of the methods used in the evaluation of the spino-pelvic parameters, comparing the application to the standard goniometer and dermatograph pencil method, the $K$ values found for the measurement of $P I, P T$, and $L L$ were 0.873 $(p<0.001), 0.939(p<0.001)$, and $0.914(p<0.001)$, respectively.

\section{DISCUSSION}

The technological advancement and popularization of smartphones, incorporating microelectromechanical systems (MEMS) technology, offered the user a new tool in the measurement of angles 


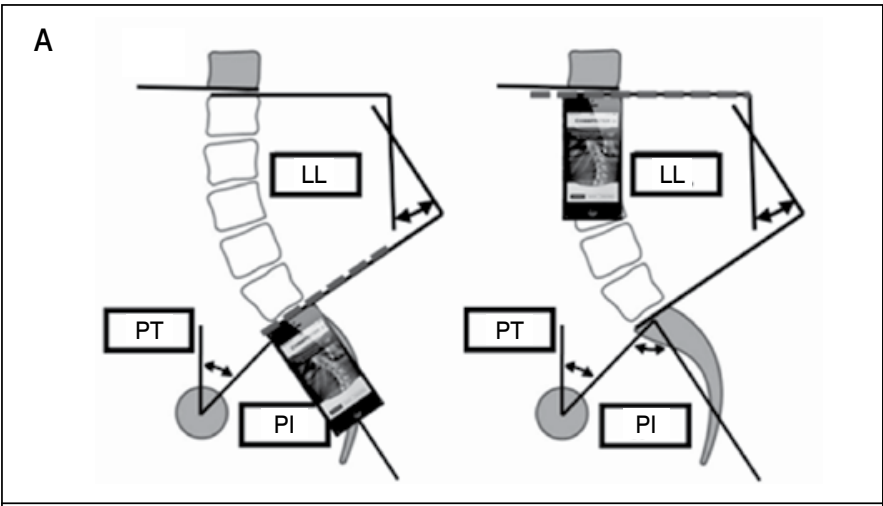

B
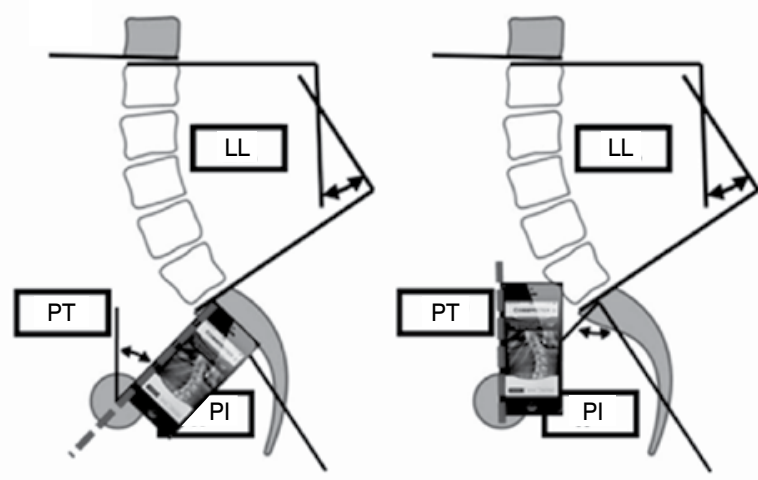

C
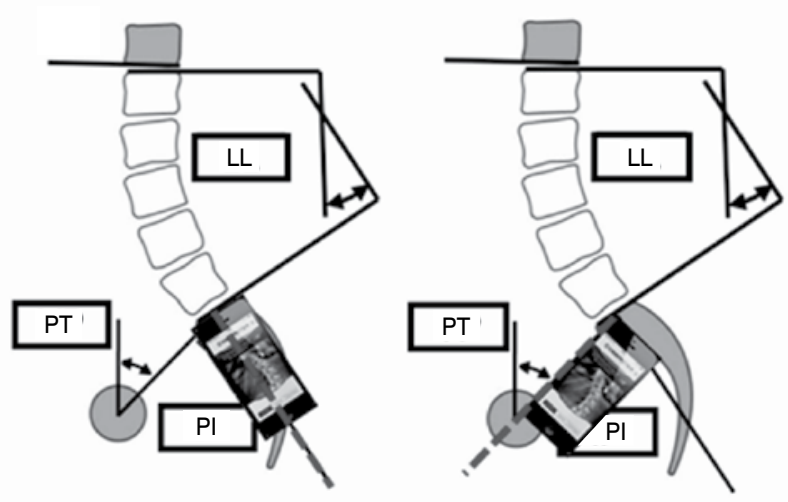

Figure 1. (A) Measurement of lumbar lordosis using the upper plateaus of vertebrae L1 and S1 and the CobbMeter application. (B) Measurement of pelvic tilt using the CobbMeter application. (C) Measurement of pelvic incidence using the CobbMeter application.

that, together with new software and applications, has had a great impact on several academic and professional areas, in our case highlighting greater efficiency and practicality in the evaluation and medical diagnosis of various spinal deformites. ${ }^{18}$ Nevertheless, there must be scientific proof that certifies the applicability and reproducibility of the technology, even though clinical decisions are being made for patients using the new technology.
The objective of this cross-sectional, non-interventional, observational study was to verify the intra- and inter-evaluator equivalence and reproducibility of the CobbMeter smartphone application in clinical practice, particularly in spine surgery, so that health professionals can rely on the use of the application to measure spino-pelvic parameters and, thus, as it becomes a more practiced methodology, user confidence will facilitate and disseminate the use of such radiographic measurements in clinical practice related to spine pathologies, directly impacting the improvement of patient care.

Thus, three evaluators conducted a set of observations of three different pelvic parameters in 20 patients using both the application and a goniometer and dermatograph pencil at three distinct instances, for a total of 1080 measurements. The study design was efficient and generated very high ICC values, showing high reliability between the methods and the evaluators. Therefore, the use of the cellular application insures measurements that are comparable and correlated to those acquired using the traditional measurement acquisition method proposed by Cobb. ${ }^{23}$

Other studies have already studied the use of smartphone applications to measure vertebral parameters, whether coronal|24,25 (Cobb angles in scoliosis) or sagittal ${ }^{15}$ (kyphosis). Unlike earlier studies, this work measured spino-pelvic sagittal angles, which involve not only vertebral plateau lines, but also imaginary lines drawn between two anatomical points (such as for example the line that joins the center of the femur heads and the center of the S1 plateau). Although these lines were not pre-drawn on an x-ray film of the spine, we saw that no pencil was needed and by simply positioning the smartphone to connect the points, it is feasible to obtain the correct measurement of the desired angle. The benefit of using the cellular application to perform radiological measurements is that it uses a device that is always on hand, unlike a dermatograph pencil and goniometer, adding yet another cell phone function besides telephone calls, email management, agenda organization, among others. Add to this the fact that it is not necessary to mark up the x-ray film itself. It is worth noting that, while proposing a change in the method of data acquisition, the objective of obtaining these measurements remains the same, which is to provide a better understanding of the pathology evaluated, giving the physician anatomical and physiological bases to propose the best therapy and achieve successful treatment. Thus, the application should be used to measure other spino-pelvic parameters in clinical practice, but other studies should be conducted to evaluate the performance of the application in each of these clinical situations.

\section{CONCLUSIONS}

The reliability analysis in this study showed a high correlation between the data obtained with the application and those obtained using the traditional method and both high intra- and inter-evaluator correlations. These results show that the tested application is equivalent to the standard method and its use is reproducible. Thus, we concluded that this tool could be used in clinical practice without issues to evaluate the sagittal alignment of the spine.

All the authors declare that there are no conflicts of interest regarding this article.

CONTRIBUTIONS OF THE AUTHORS: Each author made significant individual contributions to the development of the manuscript. LO, FF, LM, and JNN were the main contributors to the writing of the manuscript. LM, RA, RJ, and FF performed the measurement procedures. FF, LM, and JNN evaluated the statistical analysis data. LM and LO performed the bibliographical research. LM, RA, and LP contributed to the intellectual concept of the study. All the authors actively participated in discussion of the results, saw and agreed to the version of the manuscript submitted.

\section{REFERENCES}

1. Glassman SD, Bridwell K, Dimar JR, Horton W, Berven S, Schwab F. The impact of positive sagittal balance in adult spinal deformity. Spine (Phila Pa 1976). 2005;30(18):2024-9.

2. Labelle H, Mac-Thiong JM, Roussouly P. Spino-pelvic sagittal balance of spondylolisthesis: a review and classification. Eur Spine J. 2011;20(Suppl 5):641-6.
3. Lagrone MO, Bradford DS, Moe JH, Lonstein JE, Winter RB, Ogilvie JW. Treatment of symptomatic flatback after spinal fusion. J Bone Joint Surg Am. 1988;70(4):569-80.

4. Mac-Thiong JM, Berthonnaud E, Dimar JR 2nd, Betz RR, Labelle H. Sagittal alignment of the spine and pelvis during growth. Spine (Phila Pa 1976). 2004;29(15):1642-7. 
5. Mac-Thiong JM, Labelle H, Roussouly P. Pediatric sagittal alignment. Eur Spine J. 2011;20 (Suppl 5):586-90.

6. Park MS, Kelly MP, Lee DH, Min WK, Rahman RK, Riew KD. Sagittal alignment as a predictor of clinical adjacent segment pathology requiring 15 surgery after anterior cervical arthrodesis. Spine J Off J North Am Spine Soc 2014;14(7):1228-34.

7. Pellet N, Aunoble S, Meyrat R, Rigal J, Le Huec JC. Sagittal balance parameters influence indications for lumbar disc arthroplasty or ALIF. Eur Spine J. 2011;20(Suppl 5):647-62.

8. Smith-Petersen MN, Larson CB, Aufranc OE. Osteotomy of the spine for correction of flexion deformity in rheumatoid arthritis. Clin Orthop Relat Res. 1969;66:6-9.

9. Schwab F, Patel A, Ungar B, Farcy JP, Lafage V. Adult spinal deformity-postoperative standing imbalance: how much can you tolerate? An overview of key parameters in assessing alignment and planning corrective surgery. Spine (Phila Pa 1976). 2010:35(25):2224-31.

10. Vaz G, Roussouly P, Berthonnaud E, Dimnet J. Sagittal morphology and equilibrium of pelvis and spine. Eur Spine J. 2002;11(1):80-7.

11. Roussouly P, Nnadi C. Sagittal plane deformity: an overview of interpretation and management. Eur Spine J. 2010;19(11):1824-36.

12. Roussouly P, Gollogly S, Berthonnaud E, Dimnet J. Classification of the normal variation in the sagittal alignment of the human lumbar spine and pelvis in the standing position. Spine (Phila Pa 1976). 2005;30(3):346-53.

13. Rodrigues LCL, Bortoletto A, Nakao R, Azevedo VS, Beletato RM, Marques DC, et al. Lumbar Spine Surgery. Importance of Sagittal Balance in the Quality of Life of Patients. Coluna/Columna 2016;15(1):48-51.

14. Coutinho MAC, Pratali RR, Motta MM, Hoffman CB, Barsotti CEG, Santos FPE, et al. Influence of the Sagittal Balance on the Clinical Outcome in Spinal Fusion. Coluna/Columna 2016;15(1):52-6.

15. Jacquot F, Charpentier A, Khelifi S, Gastambide D, Rigal R, Sautet A. Measuring the Cobb angle with the iPhone in kyphoses: a reliability study. Int Orthop. 2012;36(8):1655-60.

16. Al-Hadithy N, Gikas PD, Al-Nammari SS. Smartphones in orthopaedics. Int Orthop. 2012;36(8):1543-7.

17. Shaw M, Adam CJ, Izatt MT, Licina P, Askin GN. Use of the iPhone for Cobb angle measurement in scoliosis. Eur Spine J. 2012;21(6):1062-8.

18. Street J, Lenehan B, Albietz J, Bishop P, Dvorak M, Fisher C. Intraobserver and interobserver reliabilty of measures of kyphosis in thoracolumbar fractures. Spine $J$. 2009;9(6):464-9.

19. Ritter R, Nagasse Y, Ribeiro I, Yamazato C, Oliveira FM, Kusabara R, et al. Comparison of Cobb Angle Measurement in Scoliosis by Residents and Spine Experts. Coluna/Columna 2016;15(1):13-6.

20. Berthonnaud E, Dimnet J, Roussouly P, Labelle H. Analysis of the sagittal balance of the spine and pelvis using shape and orientation parameters. J Spinal Disord Tech $2005 ; 18(1): 40-7$.

21. Pratali RR, Hennemann SA, Amaral R, Silva LEC, Carvalho MOP, Daher MT, et al. Standardized terminology of adult spine deformity for Brazilian Portuguese. Coluna/Columna 2015;14(4):281-5.

22. Bland JM, Altman DG. Statistical methods for assessing agreement between two methods of clinical measurement. Lancet. 1986;1(8476):307-10.

23. Cobb J. Outline for the study of scoliosis. Am Acad Orthop Surg Instr Course Lect 1948:5:261-75

24. Mazzuia AR de O, Machado DR, Fukumothi DK, Nunes LFB, Tucci Neto C, Jorge HM de $\mathrm{H}$, et al. Iphone app use to Cobb angle in adolescent idiopathic scoliosis: Does this apply? Coluna/Columna 2015;14(2):101-4.

25. Qiao J, Liu Z, Xu L, Wu T, Zheng X, Zhu Z, et al. Reliability analysis of a smartphoneaided measurement method for the Cobb angle of scoliosis. J Spinal Disord Tech 2012;25(4):E88-92 